以上に要求され，䀣垂に対して横ブレに注意を払い円滑 な作動を行なわしめるためニードル，スラストベアリン グを使用し解決を図った。

〔結果】

天井格納寸法は $650 \mathrm{~mm}$ で完全頭上格納，パンタスト ロークも 2,000 mm の好結果が得られ, 従来の保持装膡 で不可能な撮影台上より卧位遠距離撮影などにも有効 F.F.D をとるととが可能となった.

\section{2. 循環器系撮影装置における単相大電流装置の適用} 株式会社島津製作所

中西 猛・津田 元久. 柴田 邦夫

〔目的〕

循環器系摄影装置は次第に大出力化しているが，これ は極短時間撮影をするのが目的である，11000秒以下の撮影 では 3 相装置といえども単相装置に近い波形になるため， コスト安の塑相大電流装置の適用化について検討を試み た.

\section{[結果]}

闹一 $\mathrm{kVp}, \mathrm{mAs}$ で線量比較するる，3相装置の方が 線量が多いが，同一コントラストになる管電圧を選んで 比較するとほとんど差がない，実際にX線管の定格を荐 慮すると，同一コントラスト撮影では，3相の方が撮影 時間が約 $1 / 2$ となる。しかし $3 / 1000$ 秒の撮影では，単相む 3 相むほとんど同一波形になるため，同じ $1000 \mathrm{~mA}$ 形装置 では，波高值の高い単相装置の方が有利となる。

\section{質問}

(1) $\mathrm{X}$ 線の線䆏比較に単相をすべて基準にとっている が，単相の装置はX線管の $V-i$ 特性，高圧ヶーブル容量 により線量が変動しやすい。とれよりもとれらの影響の 現われない定電圧を基準にとる方が良いと思う。

(2) 等佂管電圧は同一管電圧です被写体の厚さにより 変化する. との基準点を決めなりれば比較は出来ないと 思う，又等価管電压の定義が不十分で，むしろ，放射X 線の奏効エネルギーで表現した方がよいのではないか. 佐藤 孝司 (関西)

\section{答}

(1) 単相装置ではX線管の $V \cdot i$ 特性, 高圧ケーブルの 影響があるというととですが，今回の発表では大電流領 域を問題にしているので，乙れらは無視できると思いま す.

(2) 等価管電圧が被写体厚さにより変化するのは当然 ですが，これらの変化の平均であると持考え下さい．数 值そのものの絶対值に誤差はあるかも知れませんが，乙 のテーマの論点の一つは波形が異っていても，管電压を
少しちがえれば，ほとんど同貿の写真がとれるというこ とであります。

\section{質問}

放射 X線量を Kulenkampf の契験式で求められてい るが，適用管電圧が $12 \mathrm{kVp}$ 以下で求められたもので，高 電圧域では娍弱㫑線で High energy 部分の強度が異っ てくるが，それについて。

宇山 茂樹（関西）

答

クレームカムプの式を，高電王領域まで適用するとと が不能かどうかというととですが, Radiology 100 Sept 1971に論文がありますが，乙の等価管電压と私其の求め た等価管電圧がきわめてよく接近しているとと，又すで に学会で発表されている種々の報告（実験）です，3相 の線量が単相にくらべて 1.6 倍程度と言われている点で む，かなりの電压までクレームカムプの式が適用できる あのと思好すす。

\section{3. ミニコンピュータによるX線装置の制御}

東卦玉川亡場

星 光二郎

果惄メディカル株式会社

山口临孝

挴木外科露腸病院

邨 尾 登

シャイロ式X線 TV 装置では患者を天板に締結するの で，思者は術者の缶のままに複雑な体位をとることがで きる，そとでミニコンピュータを組合せて思者の複雑な 体位を検出し，その体位と予め入力した正面腹厚とから 最適X線撮影条件を算出して自動的にX線装置を制御す るオンライン制御システムを開発した、撮影体位，X線 撮影条件等は夕イプライタで打出され記録される，との システムを使用するととによって省力化されると共に， $\mathrm{X}$ 線条件の失敗による不適正露出の写真が極めて少なく なった．との方法はX線条件設定の開ループ自動制御で あるが，これにホトタイマのような閉ループ制御を組合 せればより完全な无のになると思う。

\section{4. カセッテレス速写装置について}

日立レントゲン株式会社 柏工場設計部 島 倭文郎·池田 善雄

X線晹断に拈ける省力化，高能率化を目的として，力 セッテを使用しないでシント・フィルム100枚装てん可 能なカセッテレス速写装圆を開発した。フィルム 2 枚送 りおよびフィルムどおしのくっつきが起きないように一 